\title{
Rapid, two-pot procedure for the synthesis of dihydropyridinones; total synthesis of aza-goniothalamin
}

\author{
Thomas J. Cogswell ${ }^{1}$, Craig S. Donald ${ }^{2}$ and Rodolfo Marquez ${ }^{* 1,3, \S}$
}

\author{
Full Research Paper \\ Address: \\ ${ }^{1}$ School of Chemistry, University of Glasgow, Glasgow, G12 8QQ, \\ U.K, ${ }^{2}$ Lucideon Limited., Queens Road, Penkhull, Stoke-on-Trent, \\ Staffordshire, ST4 7LQ, U.K and ${ }^{3}$ School of Physical and Chemical \\ Sciences, University of Canterbury, Christchurch, 8140, New Zealand

Beilstein J. Org. Chem. 2020, 16, 135-139. doi:10.3762/bjoc. 16.15

Received: 06 October 2019

Accepted: 16 January 2020

Published: 28 January 2020

Associate Editor: B. Stoltz

(C) 2020 Cogswell et al.; licensee Beilstein-Institut. License and terms: see end of document.

\begin{abstract}
A fast, protecting-group-free synthesis of dihydropyridinones has been developed. Starting from commercially available aldehydes, a novel one-pot amidoallylation gave access to diene compounds in good yields. Ring-closing metathesis conditions were then employed to produce the target dihydropyridinones efficiently and in high yields.
\end{abstract}

\section{Introduction}

Six-membered nitrogen heterocycles are prevalent in many naturally occurring and biologically active compounds. As a result, their synthesis has received extensive research and wide spread publication in the literature [1-6]. Dihydropyridinones are an important subclass of heterocycles, which often feature both as useful intermediates, and as interesting species in their own right [7-13].

The relevance of dihydropyridones as lead compounds is exemplified by the detailed investigations into the synthesis and biological evaluation of aza-goniothalamin $\mathbf{1}$ and its analogues (Figure 1). (R)-(+)-Goniothalamin 2, a natural product isolated in 1967 , was shown to be cytotoxic against human leukaemia, kidney, ovarian and prostate cancer cell lines $\left(\mathrm{IC}_{50}=25 \mu \mathrm{M}\right.$, U251 cell line) [14-16]. In an attempt to increase the bioavailability of $(R)-(+)$-goniothalamin $\mathbf{2}$, aza-goniothalamin $\mathbf{1}$ was designed and synthesised; however, aza-goniothalamin $\mathbf{1}$ was found to have significantly lower biological activity compared to the parent compound ( $\mathrm{IC}_{50}=942 \mu \mathrm{M}$, U251 cell line) $[15,16]$. However, Pilli and co-workers were able to demonstrate that acylation of aza-goniothalamin $\mathbf{1}$ yielded analogues such as compound $\mathbf{3}$ with significantly improved biological profiles $\left(\mathrm{IC}_{50}=11 \mu \mathrm{M}, \mathrm{U} 251\right.$ cell line, Figure 1$)$. Thus, a path for the generation of a new class of potential anticancer agents based on the aza-goniothalamin framework was determined $[17,18]$. 
<smiles>O=C1C=CCC(/C=C/c2ccccc2)N1</smiles>

1<smiles>O=C1C=CCC(/C=C/c2ccccc2)O1</smiles>

2

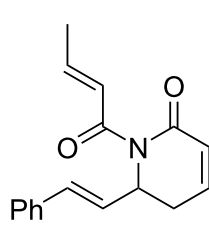

3
Figure 1: Aza-goniothalamin 1, $(R)-(+)$-goniothalamin 2 and acylated aza-goniothalamin analogue 3 [14-18].

\section{Results and Discussion}

Our approach to the synthesis of the dihydropyridinone framework was inspired by the work carried out by Veenstra and co-workers, who developed a one-pot, three-component reaction to produce protected homoallylic amines 4 (Scheme 1) [19].

It was reasoned that adaptation of the Veenstra protocol would allow us to introduce a second alkene unit during the same process, thus generating a ring-closing metathesis precursor in a single step. This general strategy towards nitrogen heterocycles has been utilized in several reports [20-23], including asymmetric variants $[24,25]$, but in these cases the ring-closing metathesis precursor was always generated in multiple steps.
In order to test this hypothesis, acrylamide was used in an analogous manner to the carbamates employed by Veenstra (Scheme 1) [19]. In our initial attempts, the solvent was changed from dichloromethane to acetonitrile due to solubility issues with the acrylamide and the postulated imine intermediate. The reaction proved sluggish, taking four days to reach completion; however, the dialkene $\mathbf{5}$ was isolated in a very encouraging $66 \%$ yield (Scheme 2).

In an attempt to increase the yield of the overall process, the reaction conditions were optimized to reach complete formation of imine $\mathbf{6}$, before treatment with allyltrimethylsilane to generate the desired product. This stepwise addition was successful in affording an improved $88 \%$ yield of diene $\mathbf{5}$ as well as significantly reducing the overall reaction time (Scheme 3 ).

Treatment of diene 5 under ring-closing metathesis conditions, using Grubbs I catalyst, then proceeded to generate the target dihydropyridinone 7 in excellent yield (Scheme 4) [20-23,26].

The scope of this concise two-pot methodology was then investigated by using a variety of different aldehydes as starting materials (Figure 2). The electron-donating aromatic substrates and the aliphatic units gave consistently high results over the 2-pot<smiles>C=CCC(Cc1ccccc1)NC(=O)Cc1ccccc1</smiles>

Scheme 1: One pot synthesis of benzyl carbamate 4 reported by Veenstra and co-workers [19].<smiles>CCOC(C)(C)CCC=[C+]=CC(N)=O</smiles><smiles>C=CCC(NC(=O)C=C)c1ccccc1</smiles>

Scheme 2: Formation of diene $\mathbf{5}$ in $66 \%$ through a one pot, three component coupling.

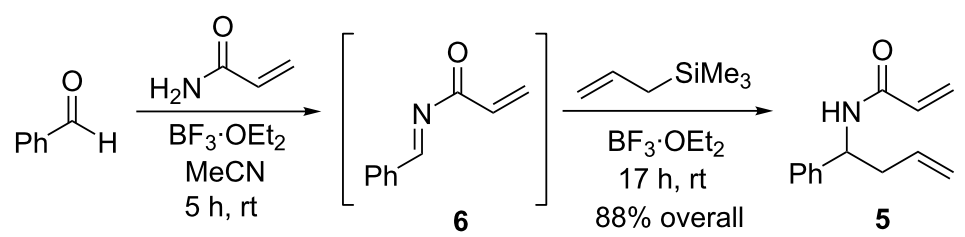

Scheme 3: Optimized conditions for the synthesis of diene 5 . 


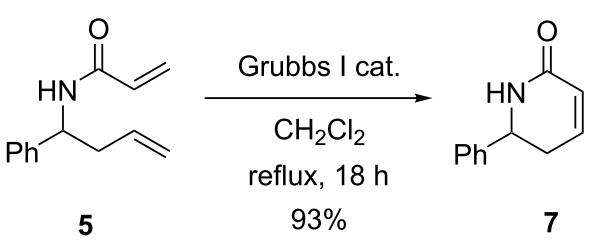

Scheme 4: Ring-closing metathesis reaction of diene 5 to yield dihydropyridone 7 [20-23]

process, producing dihydropyridinones $\mathbf{9 a}$ and $\mathbf{9 c}-\mathbf{e}$ in high yields. The electron-withdrawing substituted aromatic starting materials on the other hand, gave a low yield in the first step, which we believe was due to poor solubility of the imine intermediate. In contrast, the ring-closing metathesis reaction worked nicely to give $\mathbf{9 b}$ in $99 \%$ yield.

Having demonstrated the versatility of our approach, the synthesis of racemic aza-goniothalamin was attempted. Our synthesis began with cinnamaldehyde (Scheme 5), which was condensed with acrylamide under the same conditions described above. Rewardingly, Hosomi-Sakurai allylation of the conjugated imine intermediate proceeded to afford the desired diene $\mathbf{1 0}$ in working yield (35\%). The formation of diene $\mathbf{1 0}$ is significant as the corresponding $\alpha, \beta$-enones and $\alpha, \beta$-enals undergo exclusive conjugate addition under Hosomi-Sakurai

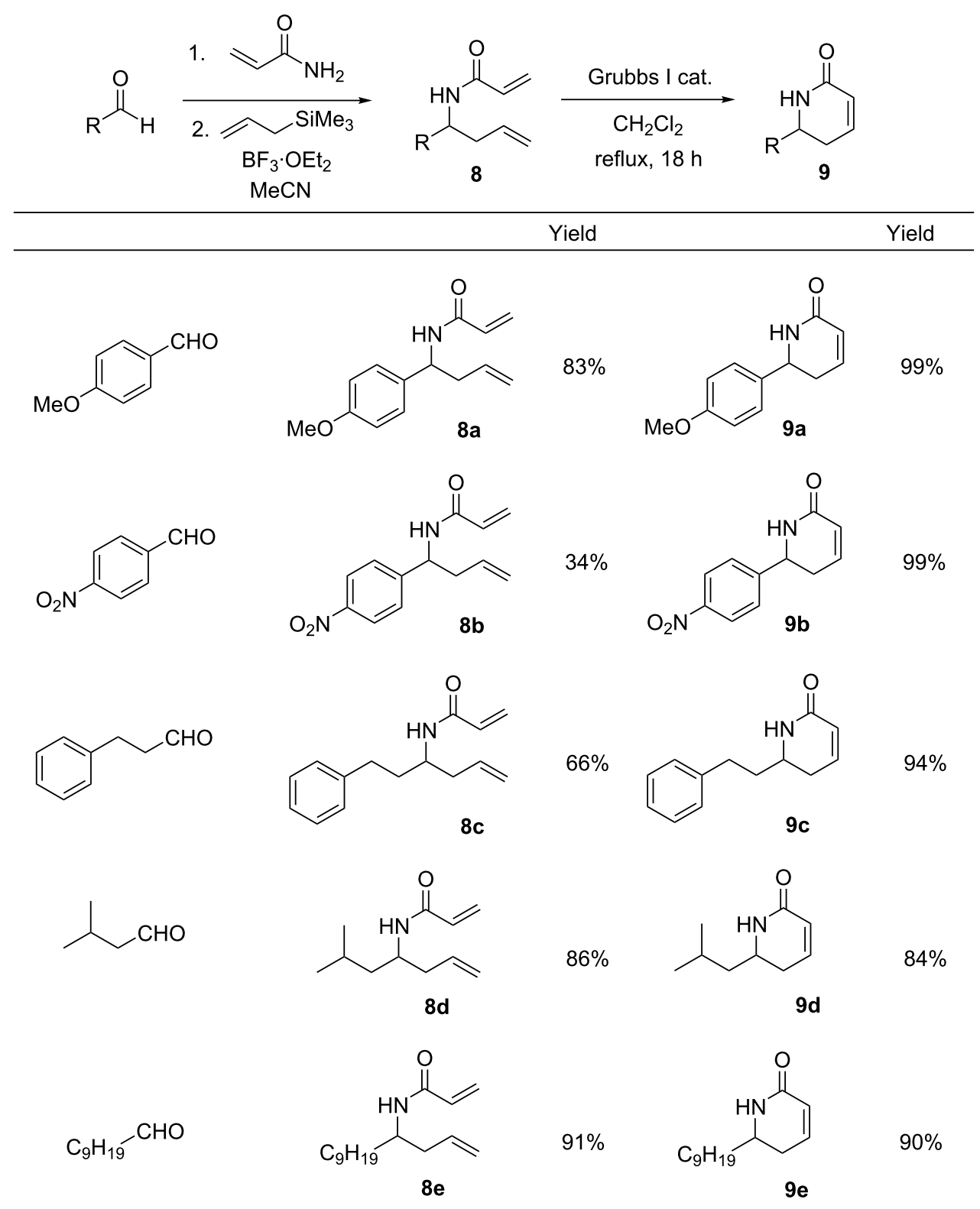

Figure 2: Extension of the two-pot methodology to include a variety of different aldehyde starting materials. 


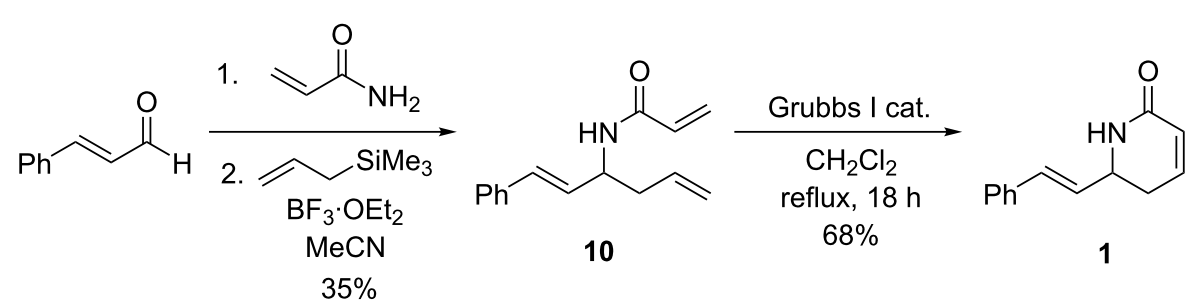

Scheme 5: Total synthesis of aza-goniothalamin 1.

conditions $[27,28]$. Ring-closing metathesis of diene $\mathbf{1 0}$ then proceeded in good yield (68\%) to complete a fast and efficient, protecting-group-free, two-pot procedure for the racemic synthesis of aza-goniothalamin $\mathbf{1}$.

\section{Conclusion}

In summary, a two-pot, protecting-group-free procedure for the synthesis of dihydropyridinones has been developed. The process requires a one-pot amidoallylation followed by a ringclosing metathesis step. This approach was used to complete the racemic synthesis of aza-goniothalamin $\mathbf{1}$, and is currently being expanded to generate new biologically relevant derivatives.

\section{Supporting Information}

\section{Supporting Information File 1}

Experimental, characterization data and copies of spectra. [https://www.beilstein-journals.org/bjoc/content/ supplementary/1860-5397-16-15-S1.pdf]

\section{Funding}

We would like to thank the EPSRC and AstraZeneca for postgraduate support (T.C.) and for a Leadership Fellowship (R.M.). The authors also thank Dr. Ian Sword and the EPSRC (grant EP/H005692/1) for funding.

\section{ORCID ${ }^{\circledR}$ iDs}

Rodolfo Marquez - https://orcid.org/0000-0001-9777-2012

\section{References}

1. Zhang, B.; Studer, A. Chem. Soc. Rev. 2015, 44, 3505-3521. doi:10.1039/c5cs00083a

2. Vo, C.-V. T.; Bode, J. W. J. Org. Chem. 2014, 79, 2809-2815. doi:10.1021/j05001252

3. Mori, M. Heterocycles 2009, 78, 281-318. doi:10.3987/rev-08-641

4. Royer, J., Ed. Asymmetric Synthesis of Nitrogen Heterocycles; Wiley-VCH: Weinheim, Germany, 2009; 10.1002/9783527625505. doi:10.1002/9783527625505

5. Liu, N.; Shu, Y.-J.; Wang, B.-Z.; Li, X.-Z.; Bi, F.-Q. Curr. Org. Chem. 2015, 19, 1896-1915. doi:10.2174/1385272819666150622174626
6. Majumdar, K. C.; Samanta, S.; Sinha, B. Synthesis 2012, 817-847. doi:10.1055/s-0031-1289734

7. Stark, D. G.; Morrill, L. C.; Yeh, P.-P.; Slawin, A. M. Z.; O'Riordan, T. J. C.; Smith, A. D. Angew. Chem., Int. Ed. 2013, 52 , 11642-11646. doi:10.1002/anie.201306786

8. Zhao, L.-L.; Li, X.-S.; Cao, L.-L.; Zhang, R.; Shi, X.-Q.; Qi, J. Chem. Commun. 2017, 53, 5985-5988. doi:10.1039/c7cc02753b

9. Yang, Y.; Hardman, C. Org. Biomol. Chem. 2017, 15, 8576-8593. doi:10.1039/c7ob01948c

10. Gao, Z.-H.; Chen, X.-Y.; Zhang, H.-M.; Ye, S. Chem. Commun. 2015, 51, 12040-12043. doi:10.1039/c5cc04593b

11. Wanner, B.; Mahatthananchai, J.; Bode, J. W. Org. Lett. 2011, 13 5378-5381. doi:10.1021/ol202272t

12. Barrow, J. C.; Nanterment, P. G.; Selnick, H. G. Dihydropyridinones and pyrrolinones useful as alpha $1 \mathrm{~A}$ adrenoceptor antagonists. U.S. Patent US6235759B1, May 22, 2001.

13. Turdi, H.; Hangeland, J. J.; Lawrence, R. M.; Cheng, D.; Ahmad, S.; Meng, W.; Brigance, P. R.; Devasthale, P.; Zhao, G. Aryl dihydropyridinones and piperidinone as MGAT2 inhibitors. Eur. Pat. Appl. EP2785693A1, Oct 8, 2014.

14. Hlubucek, J. R.; Robertson, A. V. Aust. J. Chem. 1967, 20, 2199-2206. doi:10.1071/ch9672199

15. Barcelos, R. C.; Pastre, J. C.; Caixeta, V.; Vendramini-Costa, D. B.; de Carvalho, J. E.; Pilli, R. A. Bioorg. Med. Chem. 2012, 20, 3635-3651. doi:10.1016/j.bmc.2012.03.059

16. Innajak, S.; Mahabusrakum, W.; Watanapokasin, R. Oncol. Rep. 2016, 35, 2851-2858. doi:10.3892/or.2016.4655

17. Barcelos, R. C.; Pastre, J. C.; Vendramini-Costa, D. B.; Caixeta, V.; Longato, G. B.; Monteiro, P. A.; de Carvalho, J. E.; Pilli, R. A. ChemMedChem 2014, 9, 2725-2743. doi:10.1002/cmdc.201402292

18. Barcelos, R. C.; Pelizzaro-Rocha, K. J.; Pastre, J. C.; Dias, M. P.; Ferreira-Halder, C. V.; Pilli, R. A. Eur. J. Med. Chem. 2014, 87, 745-758. doi:10.1016/j.ejmech.2014.09.085

19. Veenstra, S. J.; Schmid, P. Tetrahedron Lett. 1997, 38, 997-1000. doi:10.1016/s0040-4039(96)02458-6

20. Vanier, C.; Wagner, A.; Mioskowski, C. Chem. - Eur. J. 2001, 7, 2318-2323. doi:10.1002/1521-3765(20010601)7:11<2318::aid-chem23180>3.0.co; 2-w

21. Fiorelli, C.; Savoia, D. J. Org. Chem. 2007, 72, 6022-6028. doi:10.1021/jo0703000

22. Lucchetti, N.; Lancianesi, S.; Petrini, M. Eur. J. Org. Chem. 2014, 5433-5441. doi:10.1002/ejoc.201402116

23. Cogswell, T. J.; Donald, C. S.; Long, D.-L.; Marquez, R. Org. Biomol. Chem. 2015, 13, 717-728. doi:10.1039/c4ob01547a 24. Weilbeer, C.; Sickert, M.; Naumov, S.; Schneider, C. Chem. - Eur. J. 2017, 23, 513-518. doi:10.1002/chem.201604356 
25. Sato, M.; Azuma, H.; Daigaku, A.; Sato, S.; Takasu, K.; Okano, K.; Tokuyama, H. Angew. Chem., Int. Ed. 2017, 56, 1087-1091. doi:10.1002/anie.201609941

26. Donohoe, T. J.; Bower, J. F.; Basutto, J. A.; Fishlock, L. P.; Procopiou, P. A.; Callens, C. K. A. Tetrahedron 2009, 65, 8969-8980. doi:10.1016/j.tet.2009.07.076

27. Gong, Y.; Cao, Z.-Y.; Shi, Y.-B.; Zhou, F.; Zhou, Y.; Zhou, J. Org. Chem. Front. 2019, 6, 3989-3995. doi:10.1039/c9qo01049a

28. Lee, P. H.; Seomoon, D.; Kim, S.; Nagaiah, K.; Damle, S. V.; Lee, K. Synthesis 2003, 2189-2193. doi:10.1055/s-2003-41017

\section{License and Terms}

This is an Open Access article under the terms of the Creative Commons Attribution License

(https://creativecommons.org/licenses/by/4.0). Please note that the reuse, redistribution and reproduction in particular requires that the authors and source are credited.

The license is subject to the Beilstein Journal of Organic Chemistry terms and conditions:

(https://www.beilstein-journals.org/bjoc)

The definitive version of this article is the electronic one which can be found at: doi:10.3762/bjoc. 16.15 